\title{
Analisis Gen TCF7L2 (Trancription Factor 7 Like 2) Pada Keluarga Penderita Diabetes Mellitus Tipe 2 Kecamatan Tanggulangin, Kabupaten Sidoarjo
}

\author{
Miftahul Mushlih" ${ }^{1)}$, Siti Asriani Iknan ${ }^{1)}$, Hindah Sabrina Amin ${ }^{1)}$, Bayu Segara \& Siti \\ Cholifah $^{2)}$
}

1) Teknologi Laboratorium Medis, Fakultas Ilmu Kesehatan,

Universitas Muhammadiyah Sidoarjo, Indonesia.

2) Pendidikan Profesi Bidan, Fakultas Ilmu Kesehatan,

Universitas Muhammadiyah Sidoarjo, Indonesia.

Correspondence to: mif.mushlih@umsida.ac.id

Tanggal Submit: 26 Agustus 2020

Tanggal Review:

5 November 2020

Tanggal Publish

Online:

10 Desember 2020

\section{ABSTRACT (bahasa inggris)}

Diabetes mellitus is a metabolic disorder characterized by not produced insulin or disruption of insulin action. Diabetes mellitus was reported correlated with TCF7L2 gene mutation. This study aimed to analyze the TCF7L2 gene in families with type 2 diabetes. 5 samples were used in this study, the methods flow through DNA Isolation, PCR, and sequencing. Samples were amplified by the PCR technique using primers that were designed to detect the TCF7L2 gene, (F: 5'GGCTTGATTGTTGATTATGGGC3' and R:5 'TCTGGCACTCAGAGAGT 3'). The amplification and sequencing resulted in $368 \mathrm{bp}$ (located at 103631-103972 bp). We found a transition mutation at C103950T. The polymorphisms found may characteristic in this population because they are not found in other sequences.

Keywords : Diabetes mellitus, TCF7L2 gene, mutation

\section{PENDAHULUAN / INTRODUCTION}

Diabetes mellitus adalah suatu kelainan metabolik yang ditandai dengan tidak terproduksi insulin dengan baik dan atau tidak optimalnya produksi kinerja insulin atau diakibatkan oleh faktor keduanya ${ }^{[1]}$ Diabetes mellitus tipe 2 merupakan kelainan yang sering ditemukan di dunia. Sebanyak 90 sampai $95 \%$ orang dewasa di dunia menderita diabetes mellitus tipe $2^{[2]}$

$$
\text { Resiko terjadinya diabetes }
$$
mellitus tipe 2 akan meningkatan 2 sampai 6 kali lipat lebih tinggi ketika saudara kandung atau orang tuanya menderita penyakit tersebut ${ }^{[3]}$. Diabetes mellitus tipe 2 dapat diakibatkan oleh faktor lingkungan dan genetik ${ }^{[4]}$. 
Menurut Welcome case control consortium $^{[5]}$ menyatakan bahwa gen TCF7L2 adalah gen yang menjadi sinyal paling kuat terhadap kerentanan pada diabetes mellitus tipe 2. Pada penelitian Beloso $^{[6]}$ ditemukan mutasi gen TCF7L2 dengan varian SNPs - rs 12255372 yang menunjukkan hubungan kuat dengan diabetes mellitus tipe 2 . tipe $2^{[7] .}$

\section{METODE PENELITIAN}

Jenis penelitian ini adalah deskriptif dengan metode purposive sampling. Ethical clearance disetujui oleh Fakultas Kedotekteran Gigi Universitas Airlangga nomor 094/HRECC.FODM/III/2020. Kriteria inklusi meliputi sampel keluarga penderita diabetes mellitus yang telah di diagnosa oleh dokter, Subjek sampel bersedia di mintai keterangan silsilah keluarga yang jelas.

Sample kemudian dilakukan macrosampling sebanyak 3 cc melalui darah vena. Sampel kemudian disimpan dalam almari pendingin sampai digunakan. Isolasi DNA menggunakan metode standart dari Gene Aid DNA Isolation kit untuk darah. Amplifikasi dilakukan dengan menggunakan Biorad T100 sebanyak 35 siklus meliputi pradenaturasi, $95^{\circ} \mathrm{C}, 3$ menit; denaturasi 95 ${ }^{\circ} \mathrm{C}$, 1 menit; annealing $58^{\circ} \mathrm{C}, 30$ menit; elongasi pada suhu $72{ }^{\circ} \mathrm{C}, 1$ menit dan pre elongasi pada suhu $75^{\circ} \mathrm{C}, 3$ menit. Sekuensing gen TCF7L2 (Transcription Factor 7 Like 2) dilakukan di genetika science Indonesia kota tanggerang.

Analisis hasil sekuens mengunakan program mega 6.0, dimana urutan nukleotida sampel dan urutan nukleotida standar dimasukkan dalam program, program akan mengurutkan nukleotida sampel sesuai dengan urutan dan posisi nukleotida standar, dengan ditandai adanya basa yang berbeda sehingga akan tampak perbedaan urutan nukleotida sampel yang mengalami mutasi.

\section{HASIL PENELITIAN}

Hasil visualisasi PCR menggunakan UV transillluminator menunjukkan adanya pita DNA dengan kode sampel CD1, CD2, H1, H2, dan H3 pada 368 bp yang menandahkan adanya gen TCF7L2 (Transcription Factor 7 Like 2) pada keluarga penderita diabetes mellitus tipe 2 sesuai dengan target (Gambar 1). Gen TCF7L2 merupakan salah satu gen yang menjadi penyebab diabetes mellitus tipe $2^{[9]}$ Sebanyak 1 keluarga penderita diabetes tipe 2 yang terdiri dari 5 sampel yaitu ayah, ibu, saudara ibu, anak, dan keponakan ayah yang didapatkan dari kecamatan tanggulangin kabupaten sidoarjo. Data tersebut dapat dilihat pada gambar 1 . 


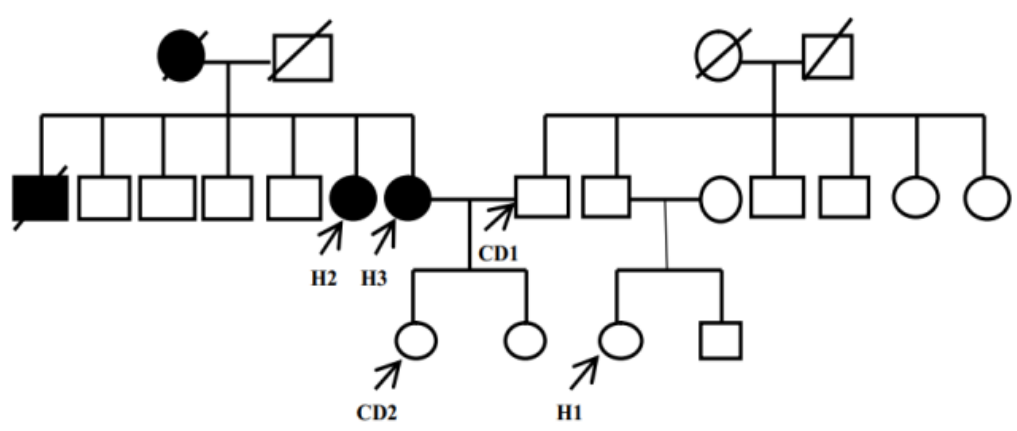

Gambar 1. sisilah keluarga penderita diabetes mellitus yang digunakan sampel.

Sebelum dilakukan pengujian analisis gula darah dilakukan dengan menggunakan metode POCT Gula darah acak. Nilai tertingg terdapat pada sampel $\mathrm{H} 2+$ dengan kadar glukosa $210 \mathrm{mg} / \mathrm{dl}$. Dan terendah adalah sampel CD2 dengan kadar gula darah $80 \mathrm{mg} / \mathrm{dl}$. Teridentifikasi dua sampel (H2+ dan $\mathrm{H} 3+)$ terdiagnosa positif DM2. Sedangkan 3 sampel lain teridentifikasi negative.

Tabel 1. Hasil Pengukuran Kadar Gula darah Keluarga sampel

\begin{tabular}{ccccc}
\hline $\begin{array}{c}\text { Kode } \\
\text { sampel }\end{array}$ & $\begin{array}{c}\text { Keluarga } \\
\text { penderita } \\
\text { DM }\end{array}$ & Umur & $\begin{array}{c}\text { Kadar } \\
\text { gula } \\
\text { darah } \\
\text { acak }\end{array}$ & Riwayat DM \\
\hline CD1 & Ayah & 55 th & $100 \mathrm{mg} / \mathrm{dl}$ & Negatif DM \\
H2+ & Ibu & 48 th & $210 \mathrm{mg} / \mathrm{dl}$ & Positif DM \\
CD2 & Anak & 22 th & $80 \mathrm{mg} / \mathrm{dl}$ & Negatif DM \\
H3+ & Bude & 50 th & $200 \mathrm{mg} / \mathrm{dl}$ & Positif DM \\
H1 & Keponakan & 24 th & $85 \mathrm{mg} / \mathrm{dl}$ & Negatif DM \\
\hline
\end{tabular}

Tabel 2. Hasil Pengukuran Kemurnian DNA hasil Isolasi

\begin{tabular}{cccccc}
\hline No & $\begin{array}{c}\text { Kode } \\
\text { sampel }\end{array}$ & A260 & A280 & $\begin{array}{c}\text { Kemurnian } \\
\text { A260/280 }\end{array}$ & konsentrasi \\
\hline 1 & CD1 & 0.409 & 0.261 & 1.569 & 184.127 \\
2 & CD2 & 0.44 & 0.275 & 1.6 & 197.859 \\
3 & H1 & 0.691 & 0.542 & 1.275 & 311.13 \\
4 & H2 & 0.592 & 0.364 & 1.627 & 266.182 \\
5 & H3 & 0.710 & 0.434 & 1.637 & 319.388 \\
\hline
\end{tabular}




\section{sampel CD1 sampel H2 sampel CD2 AL445486.1 NG_012631. sampel H3}

sampel CD1 sampel H2 sampel CD2 AL445486.1 NG_012631. sampel н3 3871082_H1

sampel $\mathrm{CD} 1$ sampel $\mathrm{H} 2$ sampel CD2 AL4 45486.1 NG 012631 . sampel $\mathrm{H} 3$ 3871082_H1

sampel $\mathrm{CD} 1$ sampel $\mathrm{H2}$ sampel CD2 AL445486. 1 NG 012631. NG_012631. 3871082 H1

sampel $\mathrm{CD} 1$ sampe1 $\mathrm{H} 2$ sampe1 $C D 2$ AL445486. 1 NG_012631. sampe1 $\mathrm{H}_{3}$ 3871082 HI

sampel $\mathrm{CD} 1$ sampe1 $\mathrm{H} 2$ sampe1 $\mathrm{CD} 2$ AL445486. 1 NG_012631 . sampel н3 3871082_H1

sampe1 CD1 sampe1 $\mathrm{H} 2$ sampe 1 H2 AL445486,1 NG 012631 . NG_012631. sampe 1 H3
3871082 H1

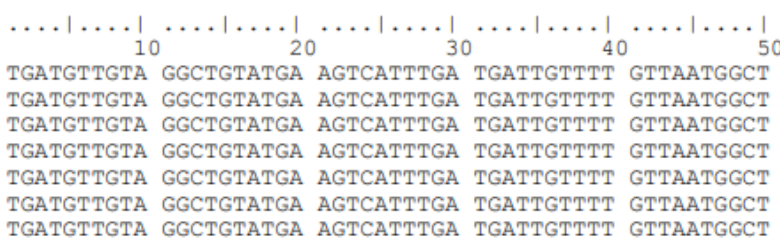

........

$\cdots+\cdots, 70$

80

90

100

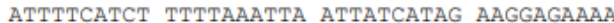
TGCAGGTCAG ATTTTCATCT TTTTAAATTA ATTATCATAG AAGGAGAAAA TGCAGGTCAG ATTTTCATCT TTTTAAATTA ATTATCATAG AAGGAGAAAA TGCAGGTCAG ATTTTCATCT TTTTAAATTA ATTATCATAG AAGGAGAAAA TGCAGGTCAG ATTTTCATCT TTTTAAATTA ATTATCATAG AAGGAGA.AAA TGCAGGTCAG ATTTTCATCT TTTTAAATTA ATTATCATAG AAGGAGAAAA TGCAGGTCAG ATTTTCATCT TTTTAAATTA ATTATCATAG AAGGAGAAA.

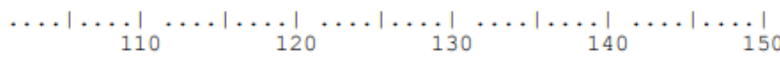

CAACTGGATT TCAGAATTGT CCCTTGAGGT GTACTGGAAA CTAAGGCGTG

CAACTGGATT TCAGAATTGT CCCTTGAGGT GTACTGGAAA CTAAGGCGTG

CAACTGGATT TCAGAATTGT CCCTTGAGGT GTACTGGAAA CTAAGGCGTG

CAACTGGATT TCAGAATTGT CCCTTGAGGT GTACTGGAAA CTAAGGCGTG

CAACTGGATT TCAGAATTGT CCCTTGAGGT GTACTGGAAA CTAAGGCGTG

CAACTGGATT TCAGAATTGT CCCTTGAGGT GTACTGGAAA CTAAGGCGTG

CAACTGGATT TCAGAATTGT CCCTTGAGGT GTACTGGAAA CTAAGGCGTG

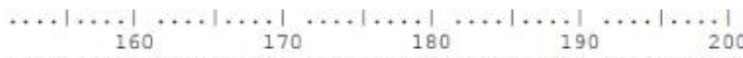
AGGGACTCAT AGGGGTCTGG CTTGGAAAGT GTATTGCTAT GTCCAGTTTA AGGGACTCAT AGGGGTCTGG CTTGGAAAGT GTATTGCTAT GTCCAGTTTA AGGGACTCAT AGGGGTCTGG CTTGGAAAGT GTATTGCTAT GTCCAGTTTA AGGGACTCAT AGGGGTCTGG CTTGGAAAGT GTATTGCTAT GTCCAGTTTA ACGGACTCAT AGGGGTCTGG CTTGGAAAGT GTATTCCTAT GTCCAGTTVA ACGCACTCAT ACGCGTCTOC CTTGCAAAGT GTATTCCTAT GTCCAGTTTM

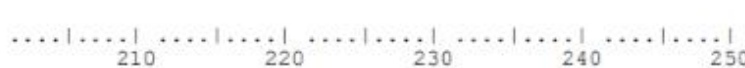

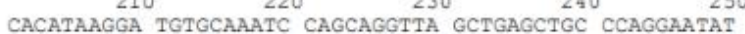
CACATAAGGA TGTGCAAATC CAGCAGGTTA GCTGAGCTGC CCAGGAATA? CACATAAGGA TGTGCAAATC CAGCAGGTTA GCTGAGCTGC CCAGGAATA CACATAAGGA TGTGCAAATC CAGCAGGTTA GCTGAGCTGC CCAGGAATAI CACATAAGGA TGTGCAAATC CAGCAGGTTA GCTGAGCTGC CCAGGAATAT CACATAAGGA TGTGCAAATC CAGCAGGTTA GCTGAGCTGC CCAGGAATAT CACATAAGGA TGTGCAAATC CAGCAGGTTA GCTGAGCTGC CCAGGAATA

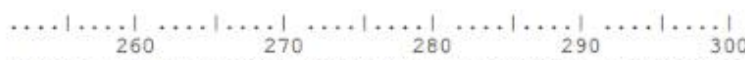

CCAGGCAAGA ATGACCATAT TCTGATAATT ACTCAGGCCT CTGCCTCATC CCAGGCAAGA ATGACCATAT TCTGATAATT ACTCAGGCCT CTGCCTCATC CCAGGCAAGA ATGACCATAT TCTGATAATT ACTCAGGCCT CTGCCTCATC CCAGGCAAGA ATGACCATAT TCTGATAATT ACTCAGGCCT CTGCCTCATC CCAGGCAAGA ATGACCATAT TCTGATAATT ACTCAGGCCT CTGCCTCATC CCAGGCAAGA ATGACCATAT TCTGATAATT ACTCAGGCCT CTGCCTCATC CCAGGCAAGA ATGACCATAT TCTGATAATT ACTCAGGCCT CTGCCTCATC

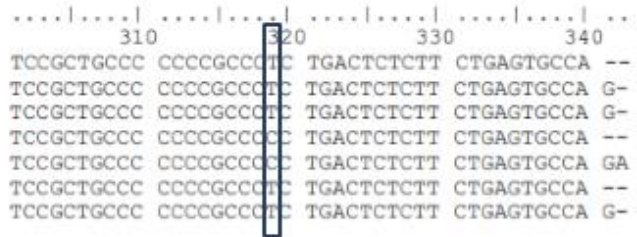

Gambar 3. Analisis hasil Allighment gen TCF7L2 di bandingkan dengan beberapa sampel dari gene bank. Keterangan: panah hitam merupakan dugaan adanya mutasi pada sampel. Titik tersebut terdapat pada $\mathrm{C} 103950 \mathrm{~T}$

Mushlih, M., iknan S.A., Amin H.S., Segara B., Cholifah S.. 2020. Analisis Gen TCF7L2 (Trancription Factor 7 Like 2) Pada Keluarga Penderita Diabetes Mellitus Tipe 2 Kecamatan Tanggulangin, Kabupaten Sidoarjo. Surabaya : The Journal of Muhamadiyah Medical Laboratory Technologist. Vol: 3, No.2 (78-85). 
Sampel kemudian di isolasi menggunakan metode solasi standart GeneAid dan dilakukan PCR selanjutnya di visualisasi menggunakan gel agarosa $2 \%$. Hasil visualisasi dapat dilihat pada gambar 2. Analisis sekuensing dilakukan dengan menggunakan bantuan software Mega 6.0 dengan menggunakan pembanding yang diambil dari genebank NCBI dengan accession Number AL445486.1, NG_012631., \& 3871082_H1. Analisis menggunakan metode pensejajaran (alignment) untuk mengetahui mutasi yang ada. Hasil analisis dapat dilihat pada gambar 3. Dari hasil Alignment didapatkan dugaan mutasi pada titik C103950T.

\section{PEMBAHASAN}

Gen TCF7L2 dilaporkan berkaitan erat dengan adanya DM Type II. Analisis pada keluarga penderit memberi gambaran kepada seseorang untuk mengetahui kemungkinan diwariskan mutasi tersebut kepada anak atau keturunannya. Analisa menggunakan sampel darah karena dinilai lebih mudah untuk diisolasi. Sampel yang digunakan dalam penelitian ini berasal dari satu keluarga dengan latar belakang memiliki DM type II.
Dalam melakukan pengecekkan kemurnian DNA hasil isolasi sampel dapat dilihat dari nilai rasio A260/A280, sampel DNA dikatakan murni jika nilai kemurniaan DNA 1,8 atau 2.0 Sedangkan syarat konsentrasi DNA yaitu $50 \mathrm{ng} / \mu \mathrm{l}$. jika nilai rasio A260/A280 kurang dari 1.8 menandakan bahwa DNA masih mengandung protein sedangkan jika nilai rasio lebih dari 2.0 menandakan bahwa penambahan pelarut lebih banyak dibandingkan DNA ${ }^{[11]}$.

Urutan basa hasil sekuensing yang sudah disejajarkan kemudian dibandingkan dengan urutan basa dari gen TCF7L2 (NG_012631) yang didapatkan dari data gen bank dan menunjukkan bahwa sampel penelitian memiliki kemiripan yang tinggi dengan gen TCF7L2 dapat dilihat dari grafik hasil blast yang menunjukkan warna merah dengan nilai quari $>200$ dan mirip dengan NG_012631.

Hasil penjajaran sekuen sampel penelitian dibandingkan dengan salah satu hasil blast yang sekiranya paling mirip dengan sekuen sampel penelitian. Dari hasil penjajaran pada Gambar 3 menunjukkan adanya mutasi jenis transisi yaitu $\mathrm{C}$ menjadi $\mathrm{T}$ dimana urutan basa nukleotida terletak pada posisi ke 103950. untuk memastikan apakah mutasi tersebut menandahkan adanya 
pewarisan gen TCF7L2 pada keturunan

penderita diabetes tipe 2 dapat dilakukan

analisis posisi mutasi pada gen TCF7L2

dan bandingkan dengan hasil penelitian

- penelitian terdahulu.

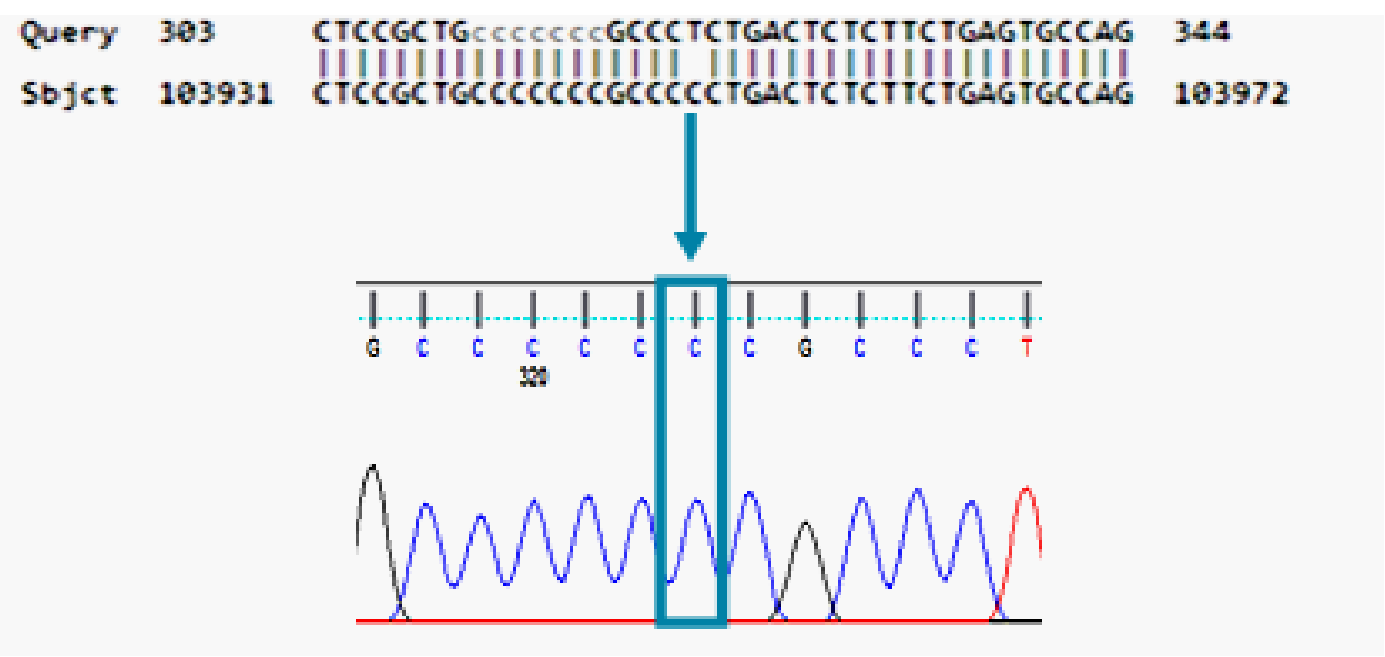

Gambar 4.6 kromagram sekuen gen TCF7L2 yang mengalami mutasi

Pada penelitan sebelumnya telah ditemukan mutasi gen TCF7L2 rs $7903146 \mathrm{C} / \mathrm{T}, \quad$ rs789834 A/G dan rs12255372 G/T yang menjadi penanda genetik diabetes mellitus tipe 2, dari masing - masing SPN tersebut posisi mutasi ada pada titik basa nukleotida ke $103894^{[14]}$ sedangkan pada penelitian ini, pada sampel pasien penderita diabetes mellitus tipe 2 dan sampel pasien yang belum menderita diabetes mellitus tipe 2 sama - sama mengalami mutasi pada urutan basa nukleotida ke 103950 dengan jenis mutasi transisi $\mathrm{C}$ menjadi $\mathrm{T}$ yang diduga sebagai penanda genetik diabetes mellitus tipe 2, namun berdasarkan hasil penelitian terdahulu tidak ditemukan titik mutasi yang sama dengan penelitian ini sehingga pada penelitian ini tidak dapat mengidentifikasi pewarisan ditebetes mellitus tipe 2 dengan penanda genetik gen TCF7L2 karena polimorfisme pada seluruh sampel sama. 


\section{KESIMPULAN / CONCLUSSION}

Hasil alignment gen TCF7L2 pada sampel keluarga penderita diabetes mellitus tipe 2 Kecamatan Tanggulangin, Kabupaten Sidoarjo ditemukan mutasi pada urutan ke T103950C. hasil tersebut mungkin menjadi penciri DM type 2 yang ada di populasi tersebut.

\section{DAFTAR PUSTAKA}

[1] Suneja, S, Christian, Y, \& Chandra, N 2018, 'Milieu of Diabetes in the 2 nd Decade of 21 st Century', Journal of Diabetes of Metabolism, vol. 9, no. 9, hh. 1-14. https://doi.org/10.4172/21556156.1000804.

[2] Petersson, C, \& Andersson, K 2010,'Standars of medical care in diabetes,'diabetic retirophaty vol. 19, no. 40, hh. 1-6. https://doi.org/10.1142/978981143 0.4443_00001.

[3] Riaz, S, 2009, 'Diabetes mellitus,'Scientific Research and Essay, vol. 4, no. 5, hh. 367-373. http://www.academicjournals.org/S RE.

[4] Shafee, T, \& Lowe, R 2017, 'Eukaryotic and prokaryotic gene structure,'WikiJournal ofMedicine, vol. 4 no. 1, hh. 2. https://doi.org/10.15347/wjm/2017. 002.
[5] 'Welcome trust case control consortium 2007, 'Genome-wide association study of 14,000 cases of seven commom diseasses and 3,000 shared controls,'Nature europe PMC funders, vol. 6, no. 447, hh. 661-678. doi:10.1038/nature05911.

[6] Beloso, C, Souto, J, \& Mimbacas, A 2018, 'Association of TCF7L2 mutation and atypical diabetes in a uruguayan population,'World Journal Of Diabetes, vol. 9, no. 9, hh. 157-164. DOI: 10.4239/wjd.v9.i9.157.

[7] Jyothi, U, \& Mohan, B 2011, 'Genetic etiology of type 2 diabetes mellitus,'Research Society For Study Of Diabetes In India, vol. 1, no. 6, hh. 3-10. DOI 10.1007/s13410-011-0020-8.

Vural, H 2017, 'gene polimorphism in $\mathrm{T} 2 \mathrm{dm}$ with patient in turkish population,'journal of clinical epigetics vol. 3, hh. 2-27. doi: 10.211767/2472-1158.100061.

[9] Yang, Q 2011, 'Harrison's Endocrinology,'In The Yale Journal of Biology and medicine, vol. 84, no. 4, hh. 497-498.

https://www.ncbi.nlm.nih.gov/p mc/articles /PMC3238314.

[10] Franca, C \& Kist, T 2002, 'Areview of DNA seguencing techniques,'Queaterly Review Of Biophzsics vol. 35, hh. 169200.

http://dx.doi.org/10.1017/50033 583502003797 
The Joumal Of Muhammadiyah Medical Laborationy Technologist

Vol.3 No.2, November2020

p-SSN: 2597-3681 e-ISSN:26142805

[11] Ridwan, M 2018, 'elektroforesis analisis elektronika terhadap

[13] Delianis, P 2010, 'Karakter biokimia genetika, 'jurnal ilmiah pendidikan tehnik elektro, vol. 2 no. 1, hh. 21-26. https://jurnal.ar-raniry.ac.id.

[12] Rahn, K, Clarke, C \& Curtiss, R 2012, 'amplifikasi urutan gen invA Salmonella thypitrium oleh reaksi berantai polimerase sebagai metode spesifik deteksi,'Salmonella. Probe molekul dan seluler,vol. 6,hh. 271-279. senyawa bioaktif bakteri simbion moluska dengan GCM,'Jurnal dan ilmu teknologi kelautan, vol. 2, no. 2, hh. 3440.

https://www.itk.fpik.ipb.ac.id/ej itkt22.

[14] Syamsuril, H 2019,'genotyping SPN rs 793146 TCF7L2 gene for detection T2DMT in indonesia melayu ethnis,'Journal of shyscs vol. 13 , no. 17, hh. 1-6. DOI: $10.1088 / 1742-6596$ 